\title{
As redes episcopais do cristianismo primitivo e seu papel na construção da Igreja cristã
}

\author{
Episcopal networks in Early Christianity and their role in building \\ the Christian Church
}

BASLEZ, M-F. Les premiers batîsseurs de l'Église: correspondances épiscopales, lie-Ille siècles. Paris: Fayard, 2016. 304 p.

\section{Pedro Luís de Toledo Piza*}

Recebido em: 31/03/2020 Aprovado em: 02/04/2020

\section{$\mathrm{P}$} elo fato de ser uma das áreas mais tradicionais da historiografia, tendo em vista sua presença em cursos logo na fundação de tantas universidades no Ocidente, a História do Cristianismo Primitivo às vezes pode aparentar produzir muito pouco de novo em termos de conhecimento científico. Parece que tudo já é conhecido, todas as teses colocadas à prova, todos os limites da área experimentados. Ledo engano. Tal discurso é prontamente dissipado por um dos livros mais recentes de Marie-Françoise Baslez, professora emérita de Sorbonne, em Paris. Seu trabalho inova não apenas na abordagem e na escolha das fontes para fundamentar sua análise, como também na inserção do tema do episcopado pré-constantiniano em debates atuais da História Antiga, que se fundamentam no estudo das redes.

A premissa de Baslez é básica, ao mesmo tempo que impressionantemente pouco abordada: em um período em que a existência do culto cristão conta com uma legalidade questionada (e, especialmente no século III, frequentemente abolida pelo poder central romano), a articulação entre bispos de diferentes localidades se dá sobretudo por meio de cartas. Ainda que algumas reuniões físicas de bispos comecem a ocorrer já na segunda metade do século II, tendo a crise montanista como esteio, mesmo elas só têm sua efetividade confirmada na medida em que suas decisões são difundidas regional e

* Mestre e doutorando pelo Programa de Pós-Graduação em História Social da Universidade de São Paulo (PPGHS/ USP), sob orientação do Prof. Dr. Norberto Luiz Guarinello. 
supra regionalmente pela redação de uma carta comum. Desse modo, segundo Baslez, a melhor fonte documental existente para analisar a atividade episcopal pré-nicena são as cartas redigidas pelos bispos de então.

Ao mesmo tempo que fundamenta bem sua premissa, a autora, no entanto, precisa enfrentar uma limitação material inerente a ela. De fato, de todos os bispos ativos entre os séculos II e III, apenas um, Cipriano de Cartago, conta com uma coleção abrangente de sua atividade epistolar. Esse fato torna o cartaginense um ator central na análise de Baslez, em conjunto com outro bispo, Dionísio de Alexandria, do qual era conhecido um vasto epistolário por Eusébio de Cesareia, legado a nós apenas em algumas cartas e fragmentos de cartas por meio de citações feitas pelo historiador em sua História Eclesiástica. Esse poderia ser um obstáculo intransponível se Baslez não soubesse articular uma variedade de outras fontes epistolares (cartas de Inácio de Antioquia, Policarpo de Esmirna, Polícrates de Éfeso, entre outros), literárias (obras de Irineu de Lyon, Tertuliano e Orígenes, por exemplo) e epigráficas (sobretudo inscrições tumulares). Desse modo, o que poderia tentadoramente se limitar a uma análise comparativa entre as correspondências e os episcopados de Cipriano de Cartago e Dionísio de Alexandria acaba se realizando como história da correspondência episcopal e do próprio episcopado na condição de construtores de uma realidade social chamada "Igreja".

É justamente com a perspectiva de levar a cabo uma análise do episcopado préconstantiniano como grupo social responsável pela construção da Igreja que Baslez faz a divisão de seus capítulos. De modo geral, pode ser dito que eles são divididos conforme os desafios para a consolidação da autoridade episcopal vão sendo iluminados na documentação pela autora. Talvez as únicas exceções sejam os primeiros dois capítulos, ao mesmo tempo contextualizantes e analíticos, voltados, respectivamente, para a caracterização da atividade episcopal conforme o background dos diversos bispos (Cipriano, em Cartago, Melito, na Ásia, Dionísio, em Alexandria...) e sua capacidade, a partir da posição que ocupava na vida eclesiástica e urbana, de construir redes de comunicação e influência fundamentais para a afirmação de sua autoridade. Nesse ponto, os três capítulos seguintes se destinam a explorar mais os fundamentos de tal autoridade: o capítulo três elenca as funções executadas pelo bispo local à frente de sua congregação específica, sobretudo do ponto de vista material; já o quarto capítulo analisa a natureza teocrática e, em muitos sentidos, excludente da autoridade episcopal a partir do questionamento feito a ela por líderes carismáticos montanistas; o capítulo cinco, por outro lado, trata do desafio imposto aos bispos pelas perseguições mais agudas do século III, quando muitos deles (sobretudo Cipriano e Dionísio, focos do capítulo) fogem das autoridades e têm seu 
exemplo confrontado com o dos confessores, cristãos cuja prisão coloca-os em posição hierárquica comparável aos líderes da comunidade.

Os capítulos seis e sete, a partir de todo o exposto anteriormente, exploram, respectivamente, dois desenvolvimentos fundamentais da autoridade episcopal de então: a prerrogativa de impor os limites doutrinários, litúrgicos e éticos aos seus fiéis (assim como à atuação de atores externos ao grupo, outros bispos incluídos) e a iniciativa na solução de conflitos visando à manutenção da unidade da congregação local. O oitavo e último capítulo, por fim, fecha o trabalho demonstrando como essas dinâmicas de autoridade do episcopado deixam de ser experiências meramente locais por meio da comunicação escrita entre os bispos; nesse sentido, o modo como os bispos comunicam a seus equânimes seus desafios e decisões vão criando a normativa responsável por "construir" a Igreja como realidade social articulada supralocalmente. Nesse contexto é que deve ser encarado o início da querela ariana do século IV, basicamente iniciada quando o bispo Alexandre de Alexandria leva a seus colegas a acusação de heresia dirigida a seu próprio presbítero, Ário.

Uma análise completa da obra em seus pontos bem-sucedidos e falhos certamente exigiria um texto muito mais longo. Para uma resenha básica, no entanto, acredito que bastam uma crítica e um elogio de caráter fundamental.

Uma crítica de base pode ser feita ao próprio desenvolvimento que Baslez faz da premissa apontada no início do texto: mesmo que seja válido considerar que a atividade escrita entre bispos era a melhor forma de estes se articularem a nível de Mediterrâneo, presumir, como a autora sugere ao longo do trabalho, que ela fosse o modo primordial de articulação inter-regional entre líderes cristãos no geral seria ignorar ou desprezar a existência de formas alternativas de liderança cristã com seus próprios meios de articulação em uma realidade social que ela, acertadamente, representa como em construção nesse período. De fato, outros líderes cristãos, como profetas e profetisas, surgem apenas como contraponto ou mesmo oposição ao episcopado, como se o segundo fosse uma realidade dada antes da aparição dos primeiros, o que é questionável em uma série de sentidos. ${ }^{1}$ Nada disso teria tanto peso se Baslez não se propusesse em apresentar os bispos como "os primeiros construtores da Igreja", ao invés de considerar o episcopado uma das múltiplas variáveis possíveis nessa construção. É um caso clássico de exacerbação do objeto pela

\footnotetext{
${ }^{1}$ Tomemos, como exemplo, a primeira carta do apóstolo Paulo aos cristãos de Corinto, de meados do século I, na qual ele trata longamente da necessidade de se adotar parâmetros para a execução da profecia (ver, por exemplo, 1 Coríntios 12-14), enquanto nada é dito a respeito de bispos (profetas, no entanto, são colocados por Paulo em segundo lugar em uma hierarquia que conta com os apóstolos em primeiro; cf. 12,28).
} 
própria escolha do objeto (óbvio que sem ignorar todo o peso cultural representado pelo episcopado na construção do próprio Ocidente).

Isso posto, vale dizer que, enquanto uma análise voltada especificamente para as dinâmicas de autoridade do episcopado, o livro de Baslez pode ser considerado bemsucedido. Certamente, não deve ser ignorado que a consideração de uma multiplicidade de formas de liderança nos primórdios do cristianismo lançaria outras luzes sobre o objeto. Ainda assim, o trabalho da autora inova quando explora a correspondência episcopal não apenas como testemunha escrita de um contexto cronologicamente longínquo, mas sobretudo como eixo de agência por parte dos mesmos bispos, visando a consolidar-se e a apoiar-se mutuamente enquanto autoridade normativa da Igreja. Esse é um elemento muito pouco explorado por outros trabalhos anteriores e contemporâneos e que abre certamente novas perspectivas para a pesquisa no campo de estudos do cristianismo primitivo.

Desse modo, é justo apontar que, como toda obra de vanguarda, o livro de Baslez não é totalizante em si mesmo, e em nenhum momento a autora pretende que o seja. Ao invés, trata-se de um livro que aponta novos caminhos, abre o debate e que, portanto, certamente merece ser colocado na roda de discussões acadêmicas brasileiras. 